\title{
Electrochemical Performances of Electroactive Nano-Layered Organic-Inorganic Perovskite Containing Trivalent Iron Ion and its Use for a DNA Biosensor Preparation
}

\author{
Jing Wu, ${ }^{1,2}$ Hanxing Liu, ${ }^{1}$ Zhidong Lin, ${ }^{3}$ and Minghe Cao ${ }^{1}$ \\ ${ }^{1}$ State Key Laboratory of Advanced Technology for Materials Synthesis and Processing, Wuhan University of Technology, \\ Wuhan 430070, China \\ ${ }^{2}$ State-key Laboratory of Chemo/Biosensing and Chemometrics, College of Chemistry and Chemical Engineering, Hunan university, \\ Changsha, Hunan 410082, China \\ ${ }^{3}$ School of Materials Science Engineering, Wuhan Institute of Technology, Wuhan, Hubei 430073, China
}

Correspondence should be addressed to Jing Wu, diamondwu@whut.edu.cn

Received 2 September 2009; Revised 11 March 2010; Accepted 18 March 2010

Academic Editor: Shi-Gang Sun

Copyright (๑) 2010 Jing Wu et al. This is an open access article distributed under the Creative Commons Attribution License, which permits unrestricted use, distribution, and reproduction in any medium, provided the original work is properly cited.

A steady nano organic-inorganic perovskite hybrid with $\left[\mathrm{H}_{2} 3-\mathrm{AMP}\right]_{3 / 2} \mathrm{Fe}(\mathrm{CN})_{6}(3-\mathrm{AMP}=3$-methylaminopyridine) was prepared in the air. The structure is an unusual layered organic-inorganic type. The resulting hybrid enveloped in paraffin to prepare $\left[\mathrm{H}_{2} 3-\mathrm{AMP}\right]_{3 / 2} \mathrm{Fe}(\mathrm{CN})_{6}$ paste electrode (HPE) shows good electrochemical activity and a couple of oxidation and reduction peaks with potential of cyclic voltammometry $(\mathrm{CV})$ at around $440 \mathrm{mV}$ and $30 \mathrm{mV}$. Compared with that on CPE, oxidation potential of $\mathrm{Fe}(\mathrm{CN})_{6}{ }^{3-}$ on HPE shifts negatively $259.7 \mathrm{mV}$ and that of reduction shifts positively $338.7 \mathrm{mV}$, which exhibits that $\left[\mathrm{H}_{2} 3-\mathrm{AMP}\right]_{3 / 2} \mathrm{Fe}(\mathrm{CN})_{6}$ can accelerate the electron-transfer to improve the electrochemical reaction reversibility. Such characteristics of $\left[\mathrm{H}_{2} 3-\mathrm{AMP}\right]_{3 / 2} \mathrm{Fe}(\mathrm{CN})_{6}$ have been employed to prepare the DNA biosensor. The single-strand DNA (ssDNA) and double-strand DNA (dsDNA) immobilized on HPE, respectively, can improve the square wave voltammometry (SWV) current and SWV potential shifts positively. The effect of $\mathrm{pH}$ was evaluated. And there is hybridization peak on SWV curve using HPE immobilized ssDNA in the complementary ssDNA solution. And HPE immobilized ssDNA can be utilized to monitor the DNA hybridization and detect complementary ssDNA, covering range from $3.24 \times 10^{-7}$ to $6.72 \times 10^{-5} \mathrm{~g} / \mathrm{mL}$ with detection limit of $1.57 \times 10^{-7} \mathrm{~g} / \mathrm{mL}$. The DNA biosensor exhibits a good stability and reproducibility.

\section{Introduction}

In recent years, layered organic-inorganic perovskite hybrids have attracted great interest of researchers. Organicinorganic perovskite hybrids offer an important opportunity to combine useful properties from two chemical realms, organic and inorganic compounds, within a single molecular scale composite. Especially, the design and generation of the organic-inorganic self-organized quantum well structure represent an approach to synthesis that offers new horizons in the context of synthetic chemistry and its possible impact on new material technology [1].

The hybrid organoammonium halometallate(II), $\left(\mathrm{RNH}_{3}\right)_{2} \mathrm{MX}_{4}$, series of layer perovskite structures have played a significant role in the development of the understanding of low-dimensional magnetic systems and, more recently, of semiconducting, optical, photoelectric materials [2-6]. So far, only organic-inorganic perovskite hybrids containing the chemical element of tin (Sn), copper $(\mathrm{Cu})$, and lead $(\mathrm{Pb})$ have been used to application [7-13]. While it is not reported that organic-inorganic perovskite hybrids were used as electrochemical materials.

On the other hand, a few organic-inorganic perovskite hybrids containing $\mathrm{M}^{3+}$ have been reported. As for conventional perovskite frameworks, trivalent metal ions halide lattices generally are composed of distorted $\mathrm{MX}_{6}(\mathrm{X}=$ halogen) octahedra. These $\mathrm{MX}_{6}$ octahedra form discrete (i.e., mononuclear) or extended (i.e., polynuclear) inorganic networks of corner-, edge-, or face-sharing octahedra, leading to an extensive family of metal (III) halogenoanions 
(e.g., $\mathrm{MX}_{4}{ }^{-}, \mathrm{MX}_{5}{ }^{2-}, \mathrm{MX}_{6}{ }^{3-}, \mathrm{M}_{2} \mathrm{X}_{9}{ }^{3-}, \mathrm{M}_{2} \mathrm{X}_{11}{ }^{5-}, \mathrm{M}_{3} \mathrm{X}_{12}{ }^{3-}$, $\mathrm{M}_{4} \mathrm{X}_{18}{ }^{6-}, \mathrm{M}_{5} \mathrm{X}_{18}{ }^{3-}, \mathrm{M}_{6} \mathrm{X}_{22}{ }^{4-}$, and $\left.\mathrm{M}_{8} \mathrm{X}_{30}{ }^{6-}\right)$. Within these networks, the inorganic sections of perovskite hybrids incline to diversification. Mitzi's group has successfully synthesized thin sheetlike crystals of the metal-deficient perovskites $\left(\mathrm{H}_{2} \mathrm{AEQT}\right) \mathrm{M}_{2 / 3} \mathrm{I}_{4} \quad\left[\mathrm{M}=\mathrm{Bi}^{3+}\right.$ or $\mathrm{Sb}^{3+}$; AEQT $=5,5$-bis(aminoethyl)-2,2:5,2:5,2-quaterthiophene] under an inert atmosphere [14]. The stability of $\left(\mathrm{H}_{2} \mathrm{AEQT}\right) \mathrm{M}_{2 / 3} \mathrm{I}_{4}$ needs to be improved. In this study, we utilized the $\mathrm{Fe}(\mathrm{CN})_{6}{ }^{3-}$ as inorganic sheets of perovskite hybrids to prepare steady layered organic-inorganic perovskite hybrids containing $\mathrm{M}^{3+}$, which to avoid the an extensive family of metal (III) halogenoanions.

In present work, we prepared layered organic-inorganic perovskite hybrid- $\left[\mathrm{H}_{2} 3-\mathrm{AMP}\right]_{3 / 2} \mathrm{Fe}(\mathrm{CN})_{6}$ by molecular scale steric interaction between 3-(methylAmino)pyridine and $\mathrm{Fe}(\mathrm{CN})_{6}{ }^{3-}$. And the microstructure of $\left[\mathrm{H}_{2} 3-\mathrm{AMP}\right]_{3 / 2}$. $\mathrm{Fe}(\mathrm{CN})_{6}$ was characterized. $\left[\mathrm{H}_{2} 3-\mathrm{AMP}\right]_{3 / 2} \mathrm{Fe}(\mathrm{CN})_{6}$ was utilized to electrochemical material. The electrochemical redox and electrocatalytic characteristics of $\left[\mathrm{H}_{2} 3-\mathrm{AMP}\right]_{3 / 2} \mathrm{Fe}(\mathrm{CN})_{6}$ were investigated by $\left[\mathrm{H}_{2} 3-\mathrm{AMP}\right]_{3 / 2} \mathrm{Fe}(\mathrm{CN})_{6}$ paste electrode (HPE). DNA biosensor based on HPE which can detect the hybridization process was explored. The interaction between DNA and $\left[\mathrm{H}_{2} 3-\mathrm{AMP}\right]_{3 / 2} \mathrm{Fe}(\mathrm{CN})_{6}$, the hybridization process, $\mathrm{pH}$ effect and linear range will be investigated in the article.

\section{Experimental Section}

2.1. Synthesis. Organic-inorganic perovskite hybrids in this study were prepared in $4 \mathrm{~mol} \cdot \mathrm{L}^{-1}$ aqueous hydrochloric acid solution in the air. Organic-inorganic perovskite hybrids were prepared by reacting potassium Ferricyanide and amine in hydrochloric acid. The ratio of AMP and potassium Ferricyanide is $3: 2$. For the $\left[\mathrm{H}_{2} 3-\mathrm{AMP}\right]_{3 / 2} \mathrm{Fe}(\mathrm{CN})_{6}$ system, a total weight of $0.491 \mathrm{~g}$ of 2-AMP $(0.162 \mathrm{~g} 1.5 \mathrm{mmol})$ and $\mathrm{K}_{3} \mathrm{Fe}(\mathrm{CN})_{6}(0.329 \mathrm{~g}, 1 \mathrm{mmol})$ were dissolved in $20 \mathrm{~mL}$ of $4 \mathrm{~mol} \cdot \mathrm{L}^{-1}$ aqueous hydrochloric acid solution. Heating was in a water bath at $65^{\circ} \mathrm{C}$ for 1 hour to form deposition. The hybrid products were filtered from which sheet-like crystals were obtained. The products were dried in vacuum drying box at $65^{\circ} \mathrm{C}$ for 12 hours and then removed to a dry box with the water levels maintained below $50 \mathrm{ppm}$. IR data: $v\left(\mathrm{NH}_{3}{ }^{\mathrm{t}}\right): 3212,3041,2952 ; \delta\left(\mathrm{NH}_{3}{ }^{\mathrm{t}}\right): 1716,1606 ; \nu$ (pyridinium): 1571, 1573, 1550, 1507; $\delta(\mathrm{Ar}-\mathrm{H}): 822,787$, $688 ; \nu\left(-\mathrm{CH}_{2-}^{-}\right): 2932,2893,2853 ; \nu\left(\mathrm{CN}^{-}\right): 2079,2166$. These TR data are similar to those in [15], which indicate that the resulting hybrid is pure. Elemental analysis: calculated for $\left(\mathrm{H}_{2} 3-\mathrm{AMP}\right)_{3 / 2} \mathrm{Fe}(\mathrm{CN})_{6}$ : C, 48.01\%; H, 3.98\%; N, 33.42\%. Found: C, 48.61\%; H, 4.12\%; N, 33.28\%.

2.2. Characterization. FT-IR spectra were measured with JASCO FT/IR-4000 infrared spectrophotometer with the $\mathrm{KBr}$ pellet technique. Elemental analyses were carried out on Vario EL instrument. The X-ray diffraction (XRD) of the powder samples was examined on a Rigaku D/Max-IIIA Xray Diffractometer (XRD) using $\mathrm{Cu}$ Ka radiation. All cyclic voltammograms data were acquired using a computer-based potentiostat/galvanostat (model 283) (EG\&GP Princeton
Applied Research, Princeton, NJ, USA). The three-electrode system consists of a sensing device, an $\mathrm{Ag} / \mathrm{AgCl}$ reference electrode, and a platinum wire as an auxiliary electrode.

2.3. Preparation of the HPE. HPE was used as the matrix electrode. It was prepared according to the procedure reported elsewhere [16] with minor modifications. In a typical process, an appropriate amount $(79.9 \mathrm{mg})$ of $\left[\mathrm{H}_{2} 3-\mathrm{AMP}\right]_{3 / 2} \mathrm{Fe}(\mathrm{CN})_{6}$ was mixed with $150.0 \mathrm{mg}$ of graphite powder and left to oscillate in ultrasonic vibrator for $2 \mathrm{~h}$ to form a homogeneous mixture. Paraffin $(149.6 \mathrm{mg})$ was dissolved in ether and dried in air about $10 \mathrm{~min}$. After evaporation of the excess of ether, the paraffin paste is mixed with the homogeneous mixture. The resulting paste was squeezed into the designed device to a depth of $1 \mathrm{~cm}$. Inside the tube, the mass was in contact with a conducting graphite rod, which was in turn connected with an electric wire to complete the measurement circuit.

2.4. Immobilization of ssDNA and dsDNA on HPE. HPE surface was first polished on a piece of emery paper, smoothed again on weighing paper, and rinsed with water. Subsequently, the cleaned HPE was immersed in $1 \mathrm{~mL}$ of tris buffer containing $50 \mu \mathrm{L}$ of $1.57 \mathrm{mg} / \mathrm{mL}$ calf thymus ssDNA at $4^{\circ} \mathrm{C}$ for 4 hours, rinsed with water. The modified electrode was then put at the same temperature to dry. Single-strand DNA was immobilized on the HPE.

The process of immobilization of calf thymus dsDNA on HPE is similar to that of immobilization of ssDNA only with ssDNA replaced with dsDNA.

2.5. Measurement Procedure. SWV measurements were performed in $10 \mathrm{~mL}$ of tris buffer of $\mathrm{pH}$ 7.2. A three-electrode system was used with a potential range from $2.0 \mathrm{mV}$ to $-1000 \mathrm{mV}$. When the background was stabilized, different volumes of solutions of $1.57 \mathrm{mg} / \mathrm{mL}$ ssDNA were added, the signal was recorded.

\section{Results and Discussion}

3.1. Characterization of $\left[\mathrm{H}_{2} 3-\mathrm{AMP}\right]_{3 / 2} \mathrm{Fe}(\mathrm{CN})_{6}$. $\left[\mathrm{H}_{2} 3-\mathrm{AMP}\right]_{3 / 2} \mathrm{Fe}(\mathrm{CN})_{6}$ hybrids crystallize in a monoclinic crystal system with space group P121 (3). The structure adopts an unusual layered organic-inorganic chain-like structure with the cell parameters $a=23.79(2) \AA, b=$ 11.49(1) $\AA, c=6.77(1) \AA, \beta=106.2(6)^{\circ}, \alpha=\gamma=90^{\circ}, Z=8$, and Volume $=1775.04$. Figure 1 shows the microstructure of $\left(\mathrm{H}_{2} 3-\mathrm{AMP}\right)_{3 / 2} \mathrm{Fe}(\mathrm{CN})_{6}$. The $\left[\mathrm{H}_{2} 3-\mathrm{AMP}\right]_{3 / 2} \mathrm{Fe}(\mathrm{CN})_{6}$ sample is composed of some regularly sandwich stacking with different thickness and each layer is around $100-200 \mathrm{~nm}$. One can see that each layer cross-section shows layered distribution, which is attributed to alternate arrangement between organic sheets and inorganic ones in the perovskite hybrids. It is well known that $\mathrm{CN}^{-}$in $\mathrm{Fe}(\mathrm{CN})_{6}{ }^{3-}$ have bridge-linked action to make organic-inorganic perovkite hybrids containing trivalent iron ions stable.

The X-ray diffraction (XRD) pattern of the sample is shown in Figure 2. The compound exhibits well-defined and 


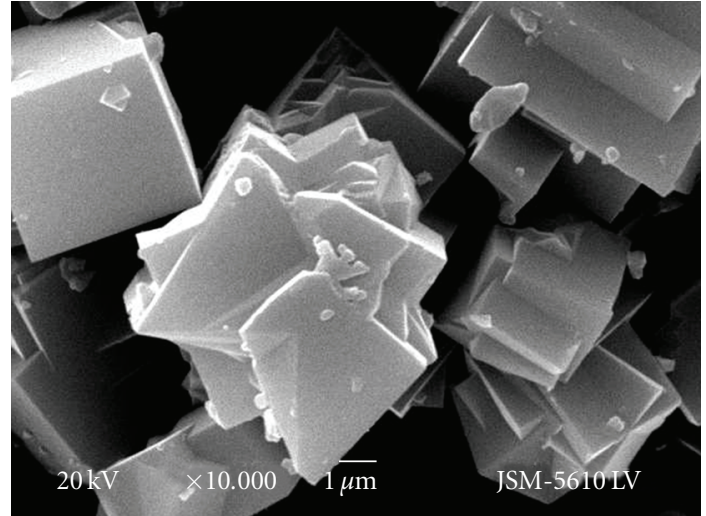

Figure 1: SEM image of $\left[\mathrm{H}_{2} 3-\mathrm{AMP}\right]_{3 / 2} \mathrm{Fe}(\mathrm{CN})_{6}$.

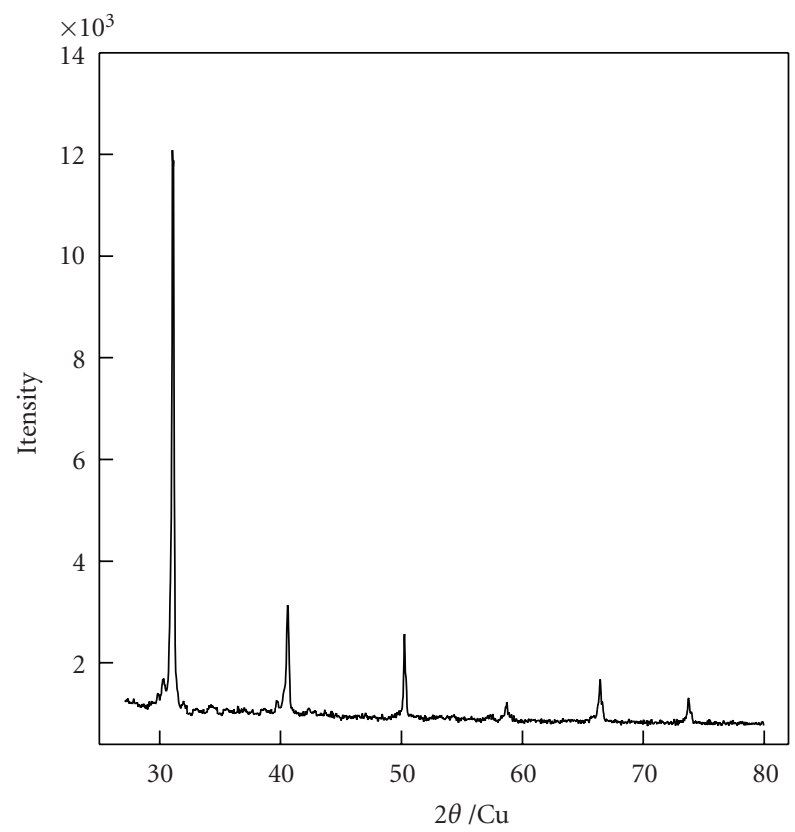

Figure 2: X-ray diffraction patterns showing the reflections of $\left[\mathrm{H}_{2} 3-\mathrm{AMP}\right]_{3 / 2} \mathrm{Fe}(\mathrm{CN})_{6}$.

equally spaced diffraction peaks. Results of the XRD study indicate that the sample- $\left[\mathrm{H}_{2} 3-\mathrm{AMP}\right]_{3 / 2} \mathrm{Fe}(\mathrm{CN})_{6}$-is well crystallized and highly oriented and has a typical layered structure. The result is consistent with that of SEM.

\subsection{Electrochemical Activity of $\left[\mathrm{H}_{2} 3-\mathrm{AMP}\right]_{3 / 2} \mathrm{Fe}(\mathrm{CN})_{6}$.} Figure $3(\mathrm{~A})$ shows the cyclic voltammometry (CV) curves of $\mathrm{HPE} 50 \mathrm{mV} / \mathrm{s}$ in $0.1 \mathrm{ml} \cdot \mathrm{L}^{-1} \mathrm{KCl}$ solution of $\mathrm{pH}$ 7.0. One notices that the curve of HPE based on $\left[\mathrm{H}_{2} 3-\mathrm{AMP}\right]_{3 / 2} \mathrm{Fe}(\mathrm{CN})_{6}$ reveals one couple of redox peaks under the potentials of around $440 \mathrm{mV}$ and $30 \mathrm{mV}$, respectively. Is the oxidation and reduction of HPE from $\mathrm{Fe}(\mathrm{CN})_{6}{ }^{3-}$, AMP, or organic-inorganic perovskite hybrids? Compared with that of $\mathrm{Fe}(\mathrm{CN})_{6}{ }^{3-}$ on carbon paste electrode (CPE) (Figure 3(B)), the oxidation peak potential shifts negatively at $193 \mathrm{mV}$ and reduction potential shifts

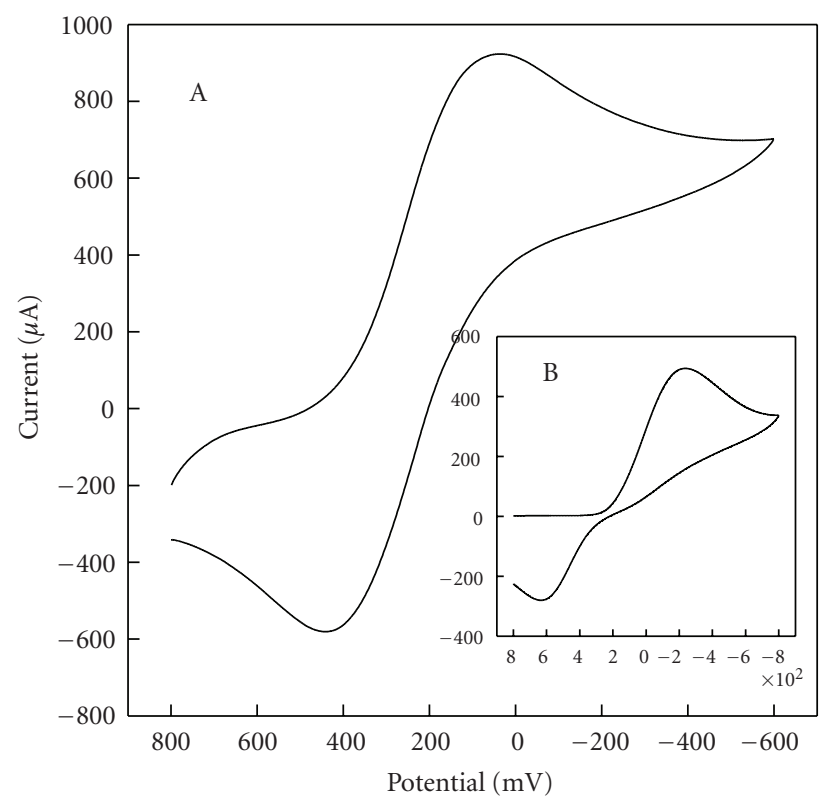

FIgure 3: Cyclic voltammograms of $\mathrm{HPE}$ in $0.1 \mathrm{~mol} \cdot \mathrm{L}^{-1} \mathrm{KCl}$ solution of $\mathrm{pH} 7.0(\mathrm{~A})$ and $\mathrm{CPE} 0.01 \mathrm{~mol} \cdot \mathrm{L}^{-1} \mathrm{Fe}(\mathrm{CN})_{6}{ }^{3-}$ containing $0.1 \mathrm{~mol} \cdot \mathrm{L}^{-1} \mathrm{KCl}$ solution of $\mathrm{pH} 7.0$ (B). scan rate: $50 \mathrm{mV} \cdot \mathrm{s}^{-1}$.

positively at $267 \mathrm{mV}$. On the other hand, it is reported that the oxidation potential of AMP is more than $1000 \mathrm{mV}$ [17]. All results demonstrate that redox process is attributed to the quasireversible redox of $\left[\mathrm{H}_{2} 3-\mathrm{AMP}\right]_{3 / 2} \mathrm{Fe}(\mathrm{CN})_{6}$ and redox activity of $\left[\mathrm{H}_{2} 3-\mathrm{AMP}\right]_{3 / 2} \mathrm{Fe}(\mathrm{CN})_{6}$ is satisfactory.

The relationship between peak current and potential scan rate can embody the redox mechanism. The influence of potential scan rate on the oxidation and reduction peak current has been investigated by cyclic voltammetry using HPE. It can be observed that the redox peak current of HPE is proportional to the root of scan rate, which indicates that the current is controlled by a semiinfinite linear diffusion. The main reason of these experimental results is that the redox chemicals $\left[\mathrm{H}_{2} 3-\mathrm{AMP}\right]_{3 / 2} \mathrm{Fe}(\mathrm{CN})_{6}$ are on the surface of HPE. On the other hand, the redox peak potential shifts slightly with the scan rate increase, which indicates that the physical and chemical properties of $\left[\mathrm{H}_{2} 3-\mathrm{AMP}\right]_{3 / 2} \mathrm{Fe}(\mathrm{CN})_{6}$ are stable.

On the basis of the above results, the redox mechanism of $\left[\mathrm{H}_{2} 3-\mathrm{AMP}\right]_{3 / 2} \mathrm{Fe}(\mathrm{CN})_{6}$ may be expressed as follows. The molecule of 3-AMP possesses the rich electron structure and easily forms $\pi$-conjugated structure, which is favorable to electron-transfer during reduction and oxidation process and promotes the $\left[\mathrm{H}_{2} 3-\mathrm{AMP}\right]_{3 / 2} \mathrm{Fe}(\mathrm{CN})_{6}$ redox behavior. On the other hand, the inorganic layers are consisted of $\mathrm{Fe}(\mathrm{CN})_{6}{ }^{3-}$ which is a typical electrochemical probe and have good reduction and oxidation characteristics. Combined with the $\mathrm{Fe}(\mathrm{CN})_{6}{ }^{3-}$ inorganic layers and 3AMP organic layers, the electrochemical characteristics of $\left[\mathrm{H}_{2} 3-\mathrm{AMP}\right]_{3 / 2} \mathrm{Fe}(\mathrm{CN})_{6}$ are more active than that of $\mathrm{Fe}(\mathrm{CN})_{6}{ }^{3-}$ and 3-AMP.

Figure 4 shows that the redox peak current of $\left[\mathrm{H}_{2} 3-\mathrm{AMP}\right]_{3 / 2} \mathrm{Fe}(\mathrm{CN})_{6}$ on electrode can be affected by the value of $\mathrm{pH}$. The redox peak current decreases with 


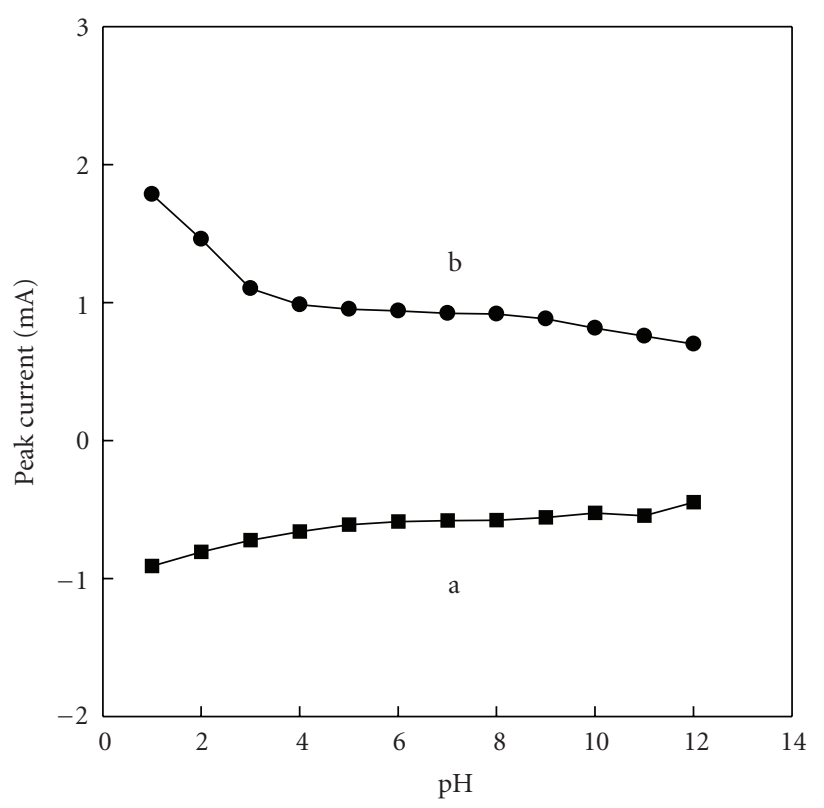

Figure 4: Effect of $\mathrm{pH}$ and the redox peak current of $\left[\mathrm{H}_{2} 3-\mathrm{AMP}\right]_{3 / 2} \mathrm{Fe}(\mathrm{CN})_{6}(\mathrm{a})$ oxidization (b) reduction.

the increase of the value of $\mathrm{pH}$, covering linear range from 1.0 to 6.0. And it is observed that the response current levels off significantly from $\mathrm{pH} 6.0$ to $\mathrm{pH} 8.0$. Above $\mathrm{pH} 8.0$, the peak current tends to directly decrease with the increase of $\mathrm{pH}$. Additionally, the redox potential shifts slightly with the change of $\mathrm{pH}$. The experimental results show that the reduction and oxidation of $\left[\mathrm{H}_{2} 3-\mathrm{AMP}\right]_{3 / 2} \mathrm{Fe}(\mathrm{CN})_{6}$ are more active in the acid solution than that in the alkaline solution. This may be attributed to the resulting hybrid which was prepared in the acid solution.

\subsection{Electrochemical Catalysis Characteristics of} $\left[\mathrm{H}_{2} 3-\mathrm{AMP}\right]_{3 / 2} \mathrm{Fe}(\mathrm{CN})_{6}$. The HPE was used to investigate the electrochemistry of $\mathrm{Fe}(\mathrm{CN})_{6}{ }^{3-}$. Using potassium ferricyanide cyclic voltammetric current recorded as a function of scan rate shows a linear $I_{p}$ versus $\mathrm{v}^{1 / 2}$ relationship covering the $10-100 \mathrm{mV} / \mathrm{s}$ range, as shown in Figure 5. This indicates that the current is controlled by a semiinfinite linear diffusion. The redox potential of $\mathrm{Fe}(\mathrm{CN})_{6}{ }^{3-}$ on HPE shifts slightly with the change of scan rate. The results indicate that catalysis action of $\left[\mathrm{H}_{2} 3-\mathrm{AMP}\right]_{3 / 2} \mathrm{Fe}(\mathrm{CN})_{6}$ is very nice and stable.

The electrochemical characteristics of HPE were studied by cyclic voltammetry in $0.1 \mathrm{ml} \cdot \mathrm{L}^{-1} \mathrm{KCl}$ solution of pH 7.0 and $20 \mathrm{mM}$ potassium ferricyanide solution at a scan rate of $50 \mathrm{mV} / \mathrm{s}$. The advantages of these new electrodes were compared with conventional $\mathrm{CPE}$, as shown in Figure 6. $\mathrm{Fe}(\mathrm{CN})_{6}^{3-}$ (Figure 6(a)) on HPE displays a couple of redox peaks with peak potential 101.3 and $373.3 \mathrm{mV}$, respectively. The oxidation and reduction potential shifts negatively $259.7 \mathrm{mV}-338.7 \mathrm{mV}$, respectively, compared with that on CPE (Figure 6(b)). For reduction and oxidation of $\mathrm{Fe}(\mathrm{CN})_{6}{ }^{3-}$, a high degree reversible reaction was observed

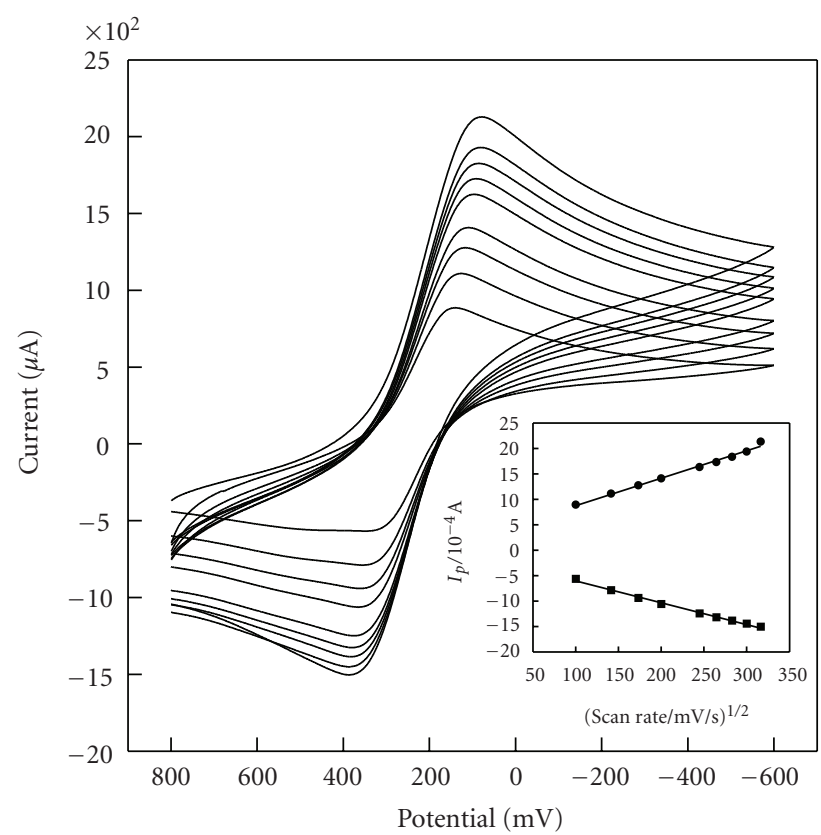

Figure 5: Cyclic voltammograms of $\mathrm{HPE}$ in $0.01 \mathrm{~mol} \cdot \mathrm{L}^{-1}$ $\mathrm{Fe}(\mathrm{CN})_{6}{ }^{3-}$ containing $0.1 \mathrm{~mol} \cdot \mathrm{L}^{-1} \mathrm{KCl}$ solution of $\mathrm{pH} 7.0$. at various scan rates (from inner to outer curves: 10, 20, 30, 40, 60, $70,80,90$, and $\left.100 \mathrm{mV} \cdot \mathrm{s}^{-1}\right)$.

at $\operatorname{HPE}\left(\Delta E_{p}=272.0 \mathrm{mV}\right)$. In fact, the electrochemical oxidation of $\mathrm{Fe}(\mathrm{CN})_{6}{ }^{3-}$ was investigated at different concentrations, ranging from $0.001 \mathrm{mM}$ to $10 \mathrm{mM}$, at HPE. There is a linear relationship between the $\mathrm{Fe}(\mathrm{CN})_{6}{ }^{3-}$ concentration and oxidation peak current with $\gamma=0.9998$. All experimental results indicate that HPE can accelerate the electrontransfer to improve the electrochemical reaction reversibility, as compared with the conventional CPE. That is to say, $\left[\mathrm{H}_{2} 3-\mathrm{AMP}\right]_{3 / 2} \mathrm{Fe}(\mathrm{CN})_{6}$ is a good kind of electrochemical catalyst.

3.4. Stability of $\left[\mathrm{H}_{2} 3-\mathrm{AMP}\right]_{3 / 2} \mathrm{Fe}(\mathrm{CN})_{6}$. The above electrochemical experiments have demonstrated that $\left[\mathrm{H}_{2} 3-\mathrm{AMP}\right]_{3 / 2} \mathrm{Fe}(\mathrm{CN})_{6}$ has good chemical and physical stability. In order to further investigate their stability, the stability of response current of HPE was carried out in $0.01 \mathrm{~mol} \cdot \mathrm{L}^{-1} \mathrm{Fe}(\mathrm{CN})_{6}{ }^{3-}$ and $0.1 \mathrm{ml} \cdot \mathrm{L}^{-1} \mathrm{KCl}$ solution by cyclic voltammetry. The variation coefficients (RSD) of HPE are $1.3 \%$ and $1.9 \%$, respectively, for five successive assays. For five interval assays, RSDs are $1.9 \%$ and $2.3 \%$, respectively. Furthermore, HPE kept in desiccator with the air for more than a month, while the redox potential changes slightly, as shown in Figure 7. The results show that HPE has a promising stability and reproducibility. From another point of view, the results demonstrate that $\left[\mathrm{H}_{2} 3-\mathrm{AMP}\right]_{3 / 2} \mathrm{Fe}(\mathrm{CN})_{6}$ has a finer electrochemical stability.

3.5. DNA Biosensor Based on $\left[\mathrm{H}_{2} 3-\mathrm{AMP}\right]_{3 / 2} \mathrm{Fe}(\mathrm{CN})_{6}$. The square wave voltammograms of HPE and HPE immobilized with ssDNA and dsDNA in tris buffer solution 


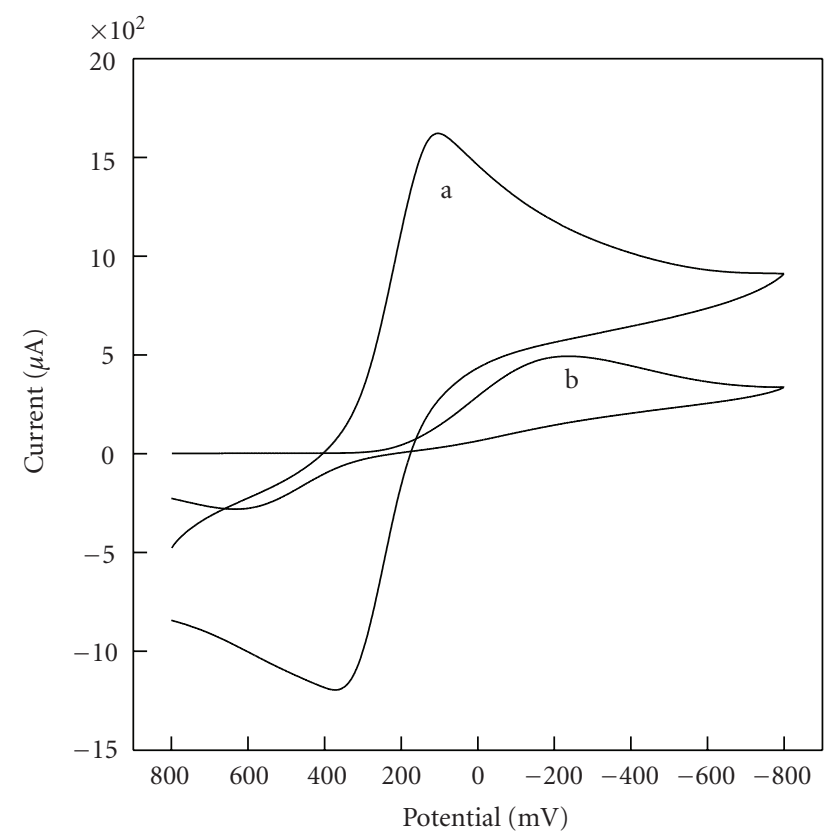

Figure 6: Cyclic voltammograms of $\operatorname{HPE}$ (a) and CPE (b) in $0.01 \mathrm{~mol} \cdot \mathrm{L}^{-1} \mathrm{Fe}(\mathrm{CN})_{6}{ }^{3-}$ containing $0.1 \mathrm{~mol} \cdot \mathrm{L}^{-1} \mathrm{KCl}$ solution of $\mathrm{pH}$ 7.0. Scan rate: $50 \mathrm{mV} \cdot \mathrm{s}^{-1}$.

are shown in Figure 8. It is obvious that two SWV peaks of $\left[\mathrm{H}_{2} 3-\mathrm{AMP}\right]_{3 / 2} \mathrm{Fe}(\mathrm{CN})_{6}$ at $840.0 \mathrm{mV}$ and $-22.8 \mathrm{mV}$ (Figure $8(\mathrm{a})$ ) are present. On HPE-immobilized ssDNA, the peak of low potential shifts positively and the other one shifts little, as shown in Figure 8(b). When HPE was immobilized with dsDNA, the two SWV peaks (863.5 and $64.0 \mathrm{mV}$, resp.) shift positively. The results demonstrate that ssDNA and dsDNA can change redox characteristics of $\left[\mathrm{H}_{2} 3-\mathrm{AMP}\right]_{3 / 2} \mathrm{Fe}(\mathrm{CN})_{6}$ and the $\left[\mathrm{H}_{2} 3-\mathrm{AMP}\right]_{3 / 2} \mathrm{Fe}(\mathrm{CN})_{6}$ has a different electrocatalytic effect on ssDNA and dsDNA.

Figures 9(a) and 9(b) show the SWVs recorded on an ssDNA-immobilized HPE in tris buffer solution with and without the complementary ssDNA. Two peaks of ssDNAimmobilized HPE (Figure 9(a)) are observed in solution without the complementary ssDNA, which is similar to that of Figure 8(b). When the electrode immobilized with ssDNA is put in the solution containing the complementary ssDNA and the SWV scan is performed again, two primary peak current decreases dramatically and a new SWV peak appears at $1.544 \mathrm{mV}$, as shown in Figure 9(b). It is possible that the new redox current is the signal of hybridization between ssDNA on HPE and the complementary ssDNA in solution. In order to further confirm the new peak being the signal of DNA hybridization, the calf thymus ssDNAimmobilized electrode is scanned in the solution containing ssDNA of fish semen, as shown in Figure 9(c). One can see that there is no peak at $1.544 \mathrm{mV}$; only the redox current of ssDNA is observed. These results show that the new peak is really a signal of hybridization, that is, HPE immobilized ssDNA can be utilized to monitor the DNA hybridization and $\left[\mathrm{H}_{2} 3-\mathrm{AMP}\right]_{3 / 2} \mathrm{Fe}(\mathrm{CN})_{6}$ can be used to prepare the DNA biosensor.

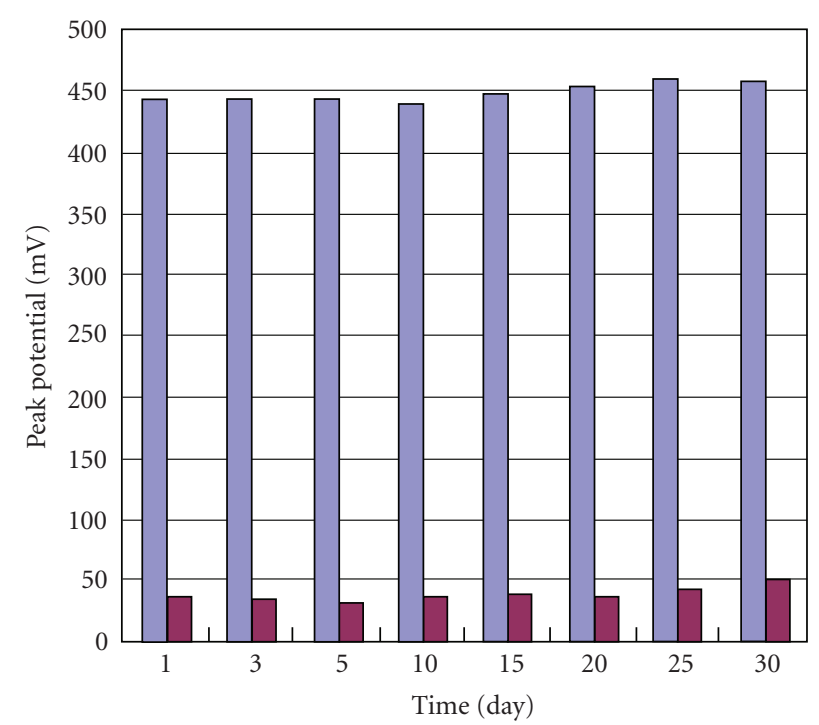

(a)

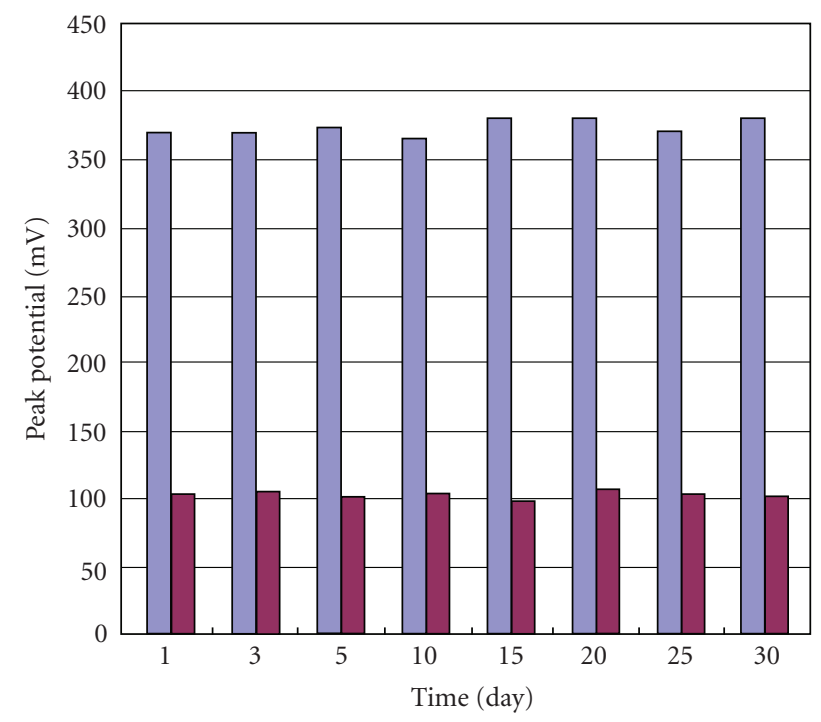

(b)

Figure 7: The relationship between redox potential and time in $0.1 \mathrm{~mol} \cdot \mathrm{L}^{-1} \mathrm{KCl}$ (a) and $0.01 \mathrm{~mol} \cdot \mathrm{L}^{-1} \mathrm{Fe}(\mathrm{CN})_{6}{ }^{3-}$ containing $0.1 \mathrm{~mol} \cdot \mathrm{L}^{-1} \mathrm{KCl}(\mathrm{b})$ solution of $\mathrm{pH}$ 7.0.

According to the above results, the interaction between $\left[\mathrm{H}_{2} 3-\mathrm{AMP}\right]_{3 / 2} \mathrm{Fe}(\mathrm{CN})_{6}$ and DNA is thought to take place in the following way. Because $\left[\mathrm{H}_{2} 3-\mathrm{AMP}\right]_{3 / 2} \mathrm{Fe}(\mathrm{CN})_{6}$ has rich $\mathrm{NH}_{3}{ }^{+}$and $\mathrm{Fe}(\mathrm{CN})_{6}$ and has unusual layered organicinorganic structural type, it may interact with ssDNA and dsDNA through ordinary interaction mechanism, that is, electrostatic interaction and hydrogen bonding, together with layered structure interactions. And ssDNA and dsDNA immobilized on HPE can change redox characteristics of $\left(\mathrm{H}_{2} 3-\mathrm{AMP}\right)_{3 / 2} \mathrm{Fe}(\mathrm{CN})_{6}$. And interaction between ssDNA and $\left[\mathrm{H}_{2} 3-\mathrm{AMP}\right]_{3 / 2} \mathrm{Fe}(\mathrm{CN})_{6}$ is different from that between dsDNA and $\left[\mathrm{H}_{2} 3-\mathrm{AMP}\right]_{3 / 2} \mathrm{Fe}(\mathrm{CN})_{6}$ which may be attributed to the different structure between ssDNA and dsDNA. 


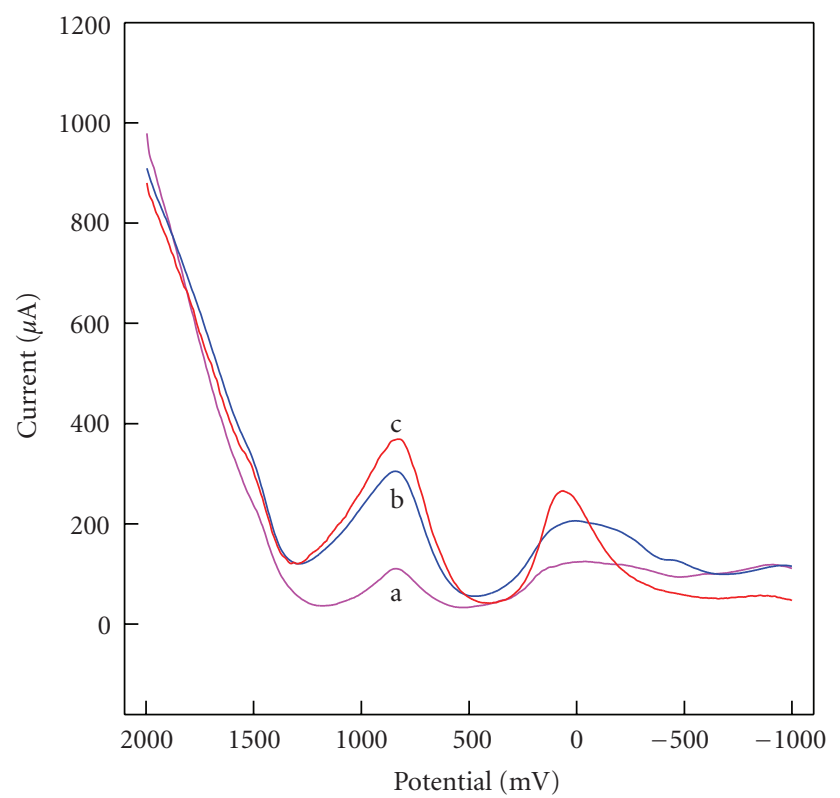

Figure 8: SWV curves using HPE (a), HPE immobilized with ssDNA (b), and HPE immobilized with dsDNA (c) in tris buffer solution.

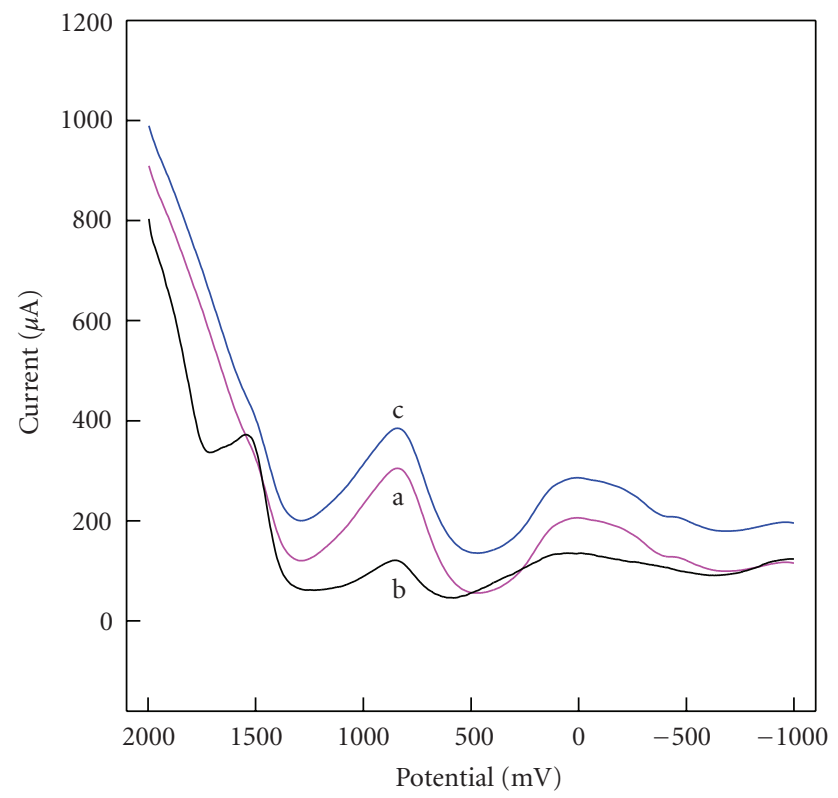

FIGURE 9: SWV curves using HPE immobilized with ssDNA in tris buffer solution (a) with the complementary ssDNA (b) and ssDNA of fish semen.

When ssDNA on HPE hybridizes with the complementary ssDNA in solution to form dsDNA, there exists an obvious change on HPE surface to affect reduction and oxidation of $\left[\mathrm{H}_{2} 3-\mathrm{AMP}\right]_{3 / 2} \mathrm{Fe}(\mathrm{CN})_{6}$. And layered structure of $\left[\mathrm{H}_{2} 3-\mathrm{AMP}\right]_{3 / 2} \mathrm{Fe}(\mathrm{CN})_{6}$ is in favor of monitoring DNA of the hybridization [18], so $\left[\mathrm{H}_{2} 3-\mathrm{AMP}\right]_{3 / 2} \mathrm{Fe}(\mathrm{CN})_{6}$ can detect the hybridization of DNA.

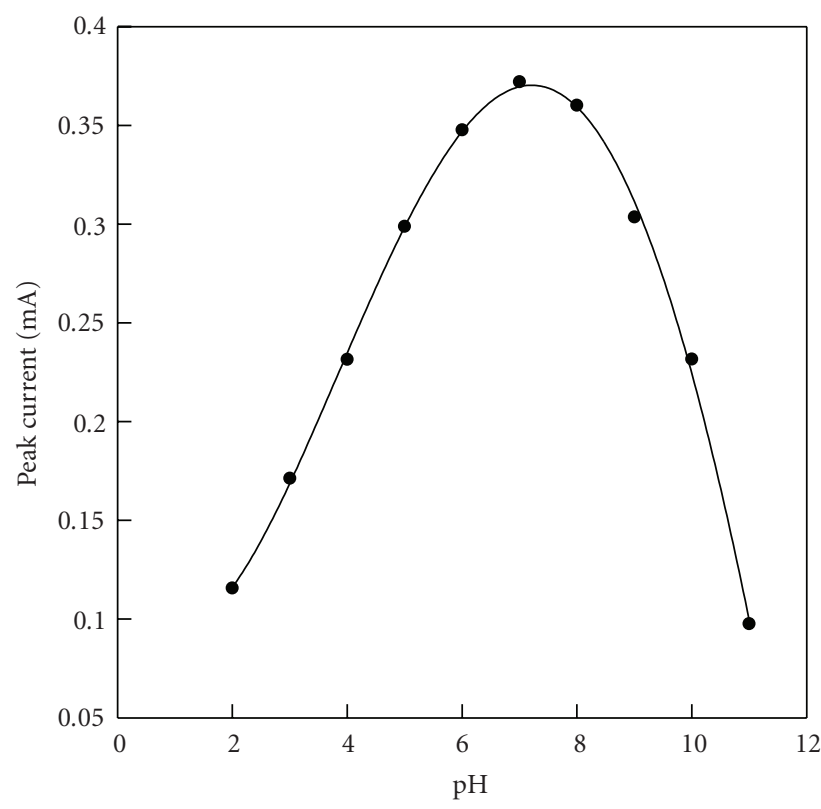

Figure 10: The relationship between the DNA hybridization peak current and $\mathrm{pH}$.

3.6. Effect of $p H$. The relationship between DNA hybridization peak current and $\mathrm{pH}$ autoxidant time from 2 to 11 was monitored as shown in Figure 10. It is observed that the response current increases significantly from $\mathrm{pH} 2$ to $\mathrm{pH}$ 6. Above $\mathrm{pH} 8$, the peak current tends to directly decrease with the increase of $\mathrm{pH}$. The DNA hybridization has maximum sensitivity around $\mathrm{pH}$ 7. Combined with the results of Figure 9, pH 7 is selected for the determination of the complementary ssDNA in solution.

3.7. The Response Characteristics of HPE Immobilized with DNA. The repeatability of response current of HPE immobilized with ssDNA and dsDNA, respectively, was investigated in tris buffer solution. The variation coefficient (RSD) was $3.9 \%$ and $3.7 \%$, respectively, for five successive assays. In the complementary ssDNA solution, HPE immobilized with ssDNA showed an acceptable reproducibility with a variation coefficient of $4.1 \%$. The results show that the DNA biosensor based on $\left[\mathrm{H}_{2} 3-\mathrm{AMP}\right]_{3 / 2} \mathrm{Fe}(\mathrm{CN})_{6}$ has a good repeatability and reproducibility.

The SWV peak current was investigated at the HPE mobilized with ssDNA using different concentrations of the complementary ssDNA. With the concentrations increasing, the peak potential appears to shift slightly. The peak current increases with the increase of the complementary ssDNA concentration. Figure 11 displays the calibration curves for the complementary ssDNA using HPE immobilized with ssDNA. A linear relationship between the peak current and the complementary ssDNA concentration in solution was obtained covering range from $3.24 \times 10^{-7}$ to $6.72 \times$ $10^{-5} \mathrm{~g} / \mathrm{mL}$. The linear regression equation is $I(\mu \mathrm{A})=$ $0.0998 \mathrm{C}\left(10^{-7} \mathrm{~g} / \mathrm{mL}\right)+110.8$, with a correlation coefficient $(\gamma)$ of 0.9932 . The detection limit is $1.57 \times 10^{-7} \mathrm{~g} / \mathrm{mL}$. These indicate that the distribution of $\left[\mathrm{H}_{2} 3-\mathrm{AMP}\right]_{3 / 2} \mathrm{Fe}(\mathrm{CN})_{6}$ in 


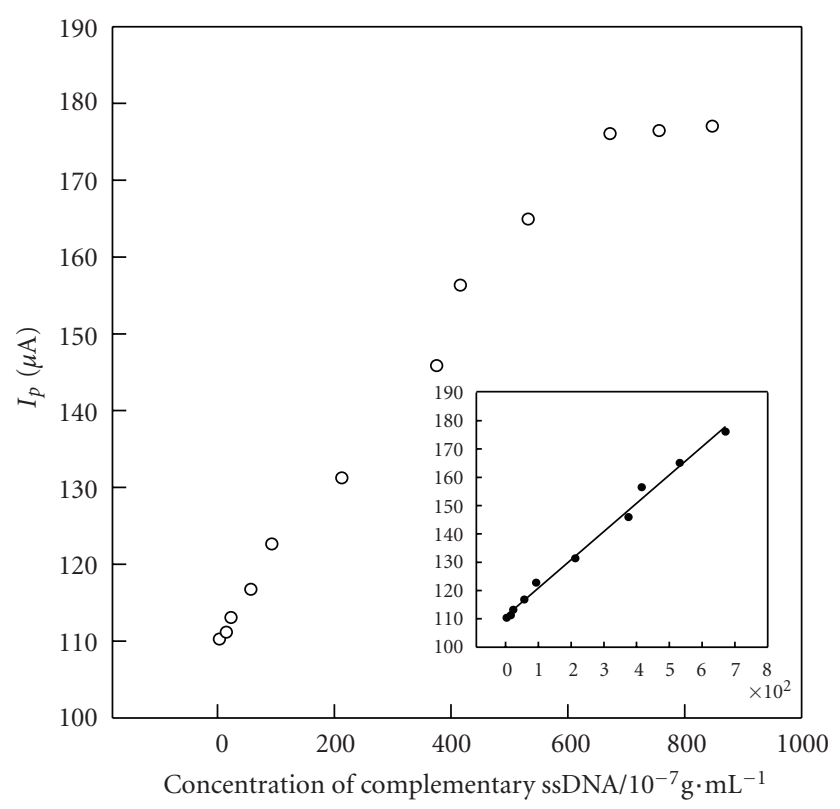

FIgURE 11: The complementary ssDNA determination using a DNA biosensor based on $\left[\mathrm{H}_{2} 3-\mathrm{AMP}\right]_{3 / 2} \mathrm{Fe}(\mathrm{CN})_{6}$.

HPE is uniform and HPE immobilized with ssDNA provides reliable results in determination of ssDNA.

\section{Conclusion}

The present study investigated the microstructure and electrochemical activity of organic-inorganic perovskite hybrid- $\left[\mathrm{H}_{2} 3-\mathrm{AMP}\right]_{3 / 2} \mathrm{Fe}(\mathrm{CN})_{6}$ in detail. By molecular scale steric interaction between 3-(methylAmino)pyridine and ferricyanide, the formation of $\left[\mathrm{H}_{2} 3-\mathrm{AMP}\right]_{3 / 2} \mathrm{Fe}(\mathrm{CN})_{6}$ is typical structure of layered organic-inorganic perovskite. $\left[\mathrm{H}_{2} 3-\mathrm{AMP}\right]_{3 / 2} \mathrm{Fe}(\mathrm{CN})_{6}$ in HPE exhibits nice electrochemical redox and electrocatalytic characteristics and the electrochemical stability is satisfactory. The paraffin$\left[\mathrm{H}_{2} 3-\mathrm{AMP}\right]_{3 / 2} \mathrm{Fe}(\mathrm{CN})_{6}$ electrode (HPE) described in this paper provides a sensitive tool for monitoring the DNA hybridization process and detection of the complementary ssDNA. A wide linear range with $\gamma=0.9932$ was obtained. The physical and chemical characteristics of HPE including mechanical stability and reproducibility of the results have been examined.

\section{Acknowledgments}

The authors are grateful to the National Natural Science Fund of China (50803047), the Postdoctoral Science Fund of China (20080431006), The Natural Science Fund of Hubei (2008CDB254), the Special Fund of Postdoctoral Science (200902460), and the Open Fund of State-key Laboratory of Chemo/Biosensing and Chemometrics (2008013) for supporting the research work.

\section{References}

[1] K. Kikuchi, Y. Takeoka, M. Rikukawa, and K. Sanui, "Fabrication and characterization of organic-inorganic perovskite films containing fullerene derivatives," Colloids and Surfaces A: Physicochemical and Engineering Aspects, vol. 257-258, pp. 199-202, 2005.

[2] D. B. Mitzi, "Synthesis, structure, and properties of organicinorganic perovskites and related materials," Progress in Inorganic Chemistry, vol. 48, p. 1, 1999.

[3] T. Matsushima, K. Fujita, and T. Tsutsui, "Electroluminescence enhancement in dry-processed organic-inorganic layered perovskite films," Japanese Journal of Applied Physics. Part 1, vol. 44, no. 3, pp. 1457-1461, 2005.

[4] C. R. Kagan, D. B. Mitzi, and C. D. Dimitrakopoulos, "Organic-inorganic hybrid materials as semiconducting channels in thin- film field-effect transistors," Science, vol. 286, no. 5441, pp. 945-947, 1999.

[5] K. Matsuishi, T. Ishihara, S. Onari, Y. H. Chang, and C. H. Park, "Optical properties and structural phase transitions of lead-halide based inorganic-organic $3 \mathrm{D}$ and $2 \mathrm{D}$ perovskite semiconductors under high pressure," Physica Status Solidi (B) Basic Research, vol. 241, no. 14, pp. 3328-3333, 2004.

[6] R. D. Willett, C. J. Gómez-García, and B. Twamley, "Structure and magnetic properties of $[(R E D A) C I]_{2} \mathrm{CuCl}_{4}$ salts: a new series of ferromagnetic layer perovskites," Polyhedron, vol. 24, no. 16-17, pp. 2293-2298, 2005.

[7] Y. Y. Li, C. K. Lin, G. L. Zheng, et al., "Novel $\langle 110\rangle$-oriented organic-inorganic perovskite compound stabilized by $\mathrm{N}$-(3aminopropyl)imidazole with improved optical properties," Chemistry of Materials, vol. 18, no. 15, pp. 3463-3469, 2006.

[8] K. Shibuya, M. Koshimizu, Y. Takeoka, and K. Asai, "Scintillation properties of $\left(\mathrm{C}_{6} \mathrm{H}_{13} \mathrm{NH}_{3}\right)_{2} \mathrm{Pbl}_{4}$ : exciton luminescence of an organic/inorganic multiple quantum well structure compound induced by $2.0 \mathrm{MeV}$ protons," Nuclear Instruments and Methods in Physics Research Section B, vol. 194, no. 2, pp. 207-212, 2002.

[9] J. L. Knutson, J. D. Martin, and D. B. Mitzi, "Tuning the band gap in hybrid tin iodide perovskite semiconductors using structural templating," Inorganic Chemistry, vol. 44, no. 13, pp. 4699-4705, 2005.

[10] Z. Xu, D. B. Mitzi, C. D. Dimitrakopoulos, and K. R. Maxcy, "Semiconducting perovskites $\left(2-\mathrm{XC}_{6} \mathrm{H}_{4} \mathrm{NH}_{3}\right)_{2} \mathrm{Snl}_{4}(\mathrm{X}=\mathrm{F}$, $\mathrm{Cl}, \mathrm{Br})$ : steric interaction between the organic and inorganic layers," Inorganic Chemistry, vol. 42, no. 6, pp. 2031-2039, 2003.

[11] A. Lappas, A. Zorko, E. Wortham, et al., "Low-energy magnetic excitations and morphology in layered hybrid perovskite-poly(dimethylsiloxane) nanocomposites," Chemistry of Materials, vol. 17, no. 5, pp. 1199-1207, 2005.

[12] Z.-L. Xiao, H.-Z. Chen, M.-M. Shi, G. Wu, and R. Zhou, "Preparation and characterization of organic-inorganic hybrid perovskite $\left(\mathrm{C}_{4} \mathrm{H}_{9} \mathrm{NH}_{3}\right)_{2} \mathrm{CuCl}_{4}$," Materials Science and Engineering B, vol. 117, no. 3, pp. 313-316, 2005.

[13] M. Era, T. Kobayashi, and M. Noto, "PbBr-based layered perovskite organic-inorganic superlattice having holetransporting carbazole chromophore in organic layer," Current Applied Physics, vol. 5, no. 1, pp. 67-70, 2005.

[14] D. B. Mitzi, "organic-inorganic perovskites containing trivalent metal halide layers: the templating influence of the organic cation layer," Inorganic Chemistry, vol. 39, no. 26, pp. 6107$6113,2000$.

[15] Y. Li, G. Zheng, C. Lin, and J. Lin, "Synthesis, structure and optical properties of different dimensional organic-inorganic 
perovskites," Solid State Sciences, vol. 9, no. 9, pp. 855-861, 2007.

[16] G. D. Liu, Z. W. Wu, S. P. Wang, G. L. Shen, and R. Q. Yu, "Renewable amperometric im- munosensor for Schistosoma japonium antibody assay," Analytical Chemistry, vol. 73, pp. 3219-3226, 2001.

[17] J. Wu, G. Liu, S. Huang, and R. Yu, "Electrochemical behavior of 2-pyridinamine modified glassy carbon electrode and its application to the determination of ascorbic acid," Chinese Journal of Analytical Chemistry, vol. 29, no. 10, pp. 1142-1143, 2001.

[18] J. Wu, Y. Zou, X. Li, H. Liu, G. Shen, and R. Yu, "A biosensor monitoring DNA hybridization based on polyaniline intercalated graphite oxide nanocomposite," Sensors and Actuators B, vol. 104, no. 1, pp. 43-49, 2005. 


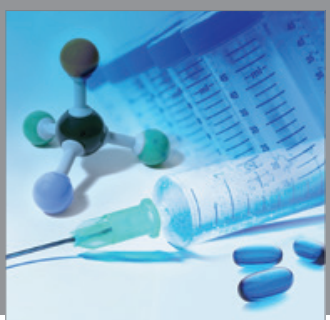

International Journal of

Medicinal Chemistry

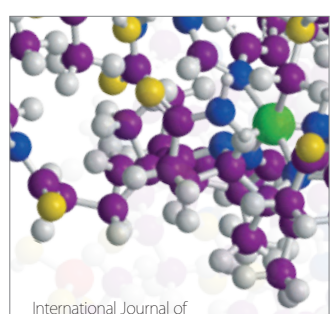

Carbohydrate Chemistry

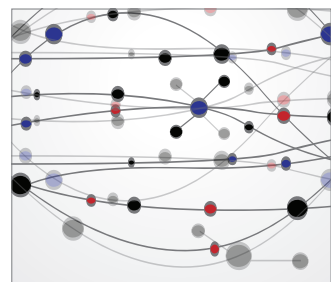

The Scientific World Journal
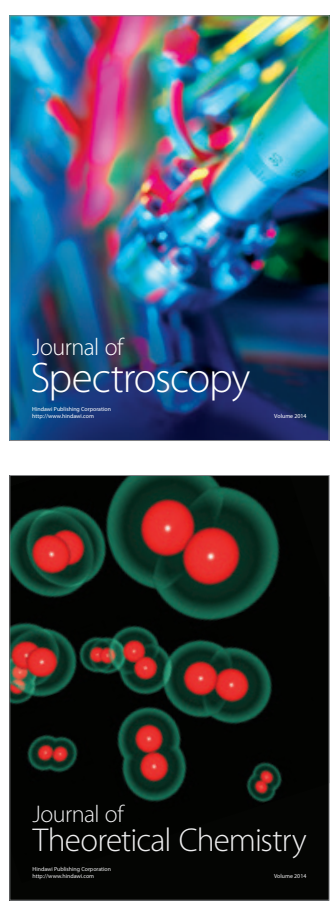
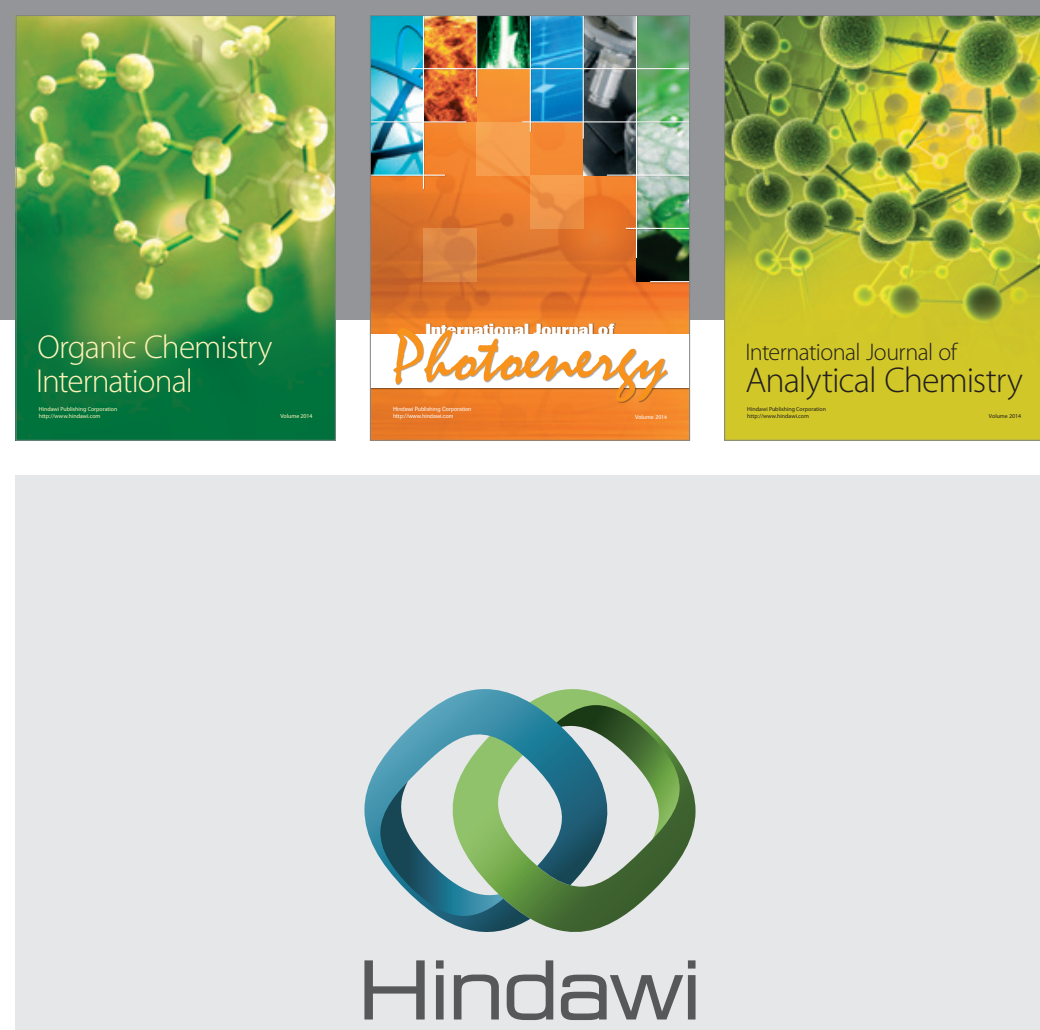

Submit your manuscripts at

http://www.hindawi.com
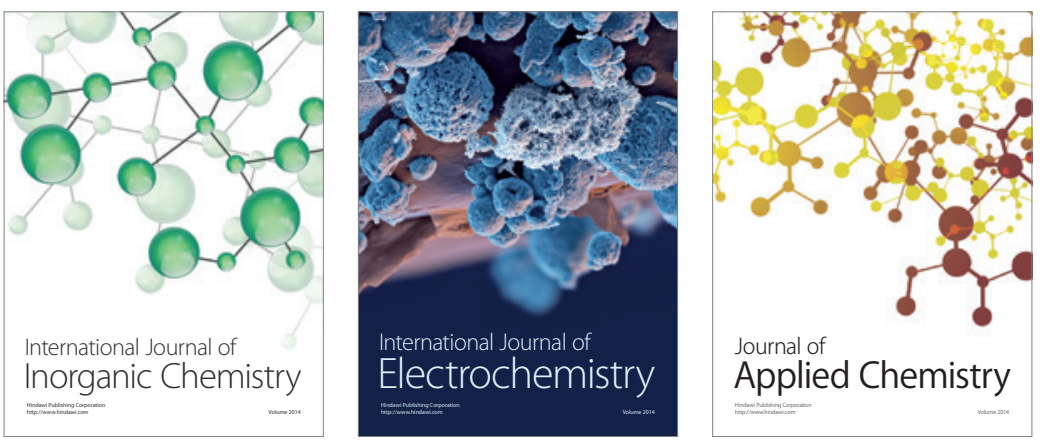

Journal of

Applied Chemistry
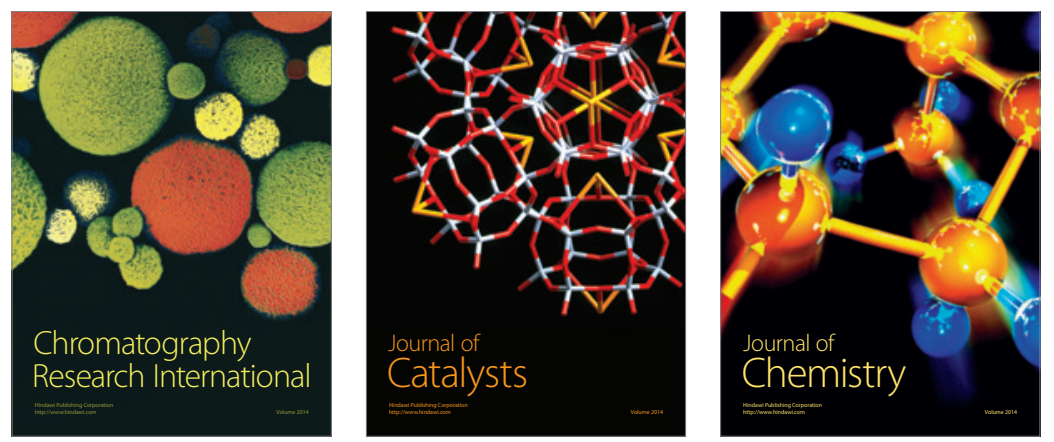
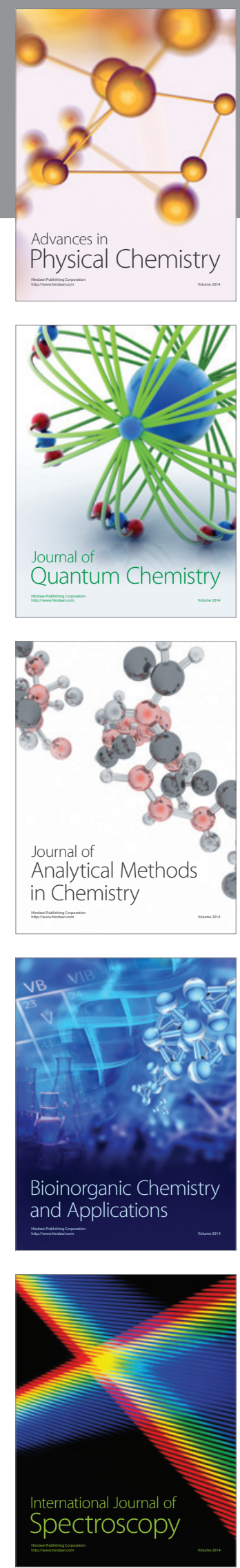